\title{
Diyabet Hastalarında Hastalık Algısının Anksiyete ve Depresyon Belirtileri Üzerine Etkisi
}

\author{
Funda Kavak®, Ümmühan Aktürk@
}

İnönü Üniversitesi, Sağlık Bilimleri Fakültesi, Hemşirelik Bölümü, Malatya, Türkiye

Funda Kavak, Dr. Öğr. Üyesi Ümmühan Aktürk, Dr. Öğr. Üyesi

İletişim:

Dr. Öğr. Üyesi Ümmühan Aktürk İnönü Üniversitesi, Sağlık Bilimleri Fakültesi, Hemşirelik Bölümü, Malatya, Türkiye Tel: +905053911305

E-Posta:ummuhan_akturk@hotmail.com

Gönderilme Tarihi : 02 Mart 2018

Revizyon Tarihi : 24 Mart 2018

Kabul Tarihi $\quad$ : 26 Mart 2018

\section{ÖZET}

Amaç: Bu çalışma; diyabet hastalarının (Tip1-2) hastalık algılarını, anksiyete ve depresyon düzeyi saptamak ve hastalık algııının anksiyete ve depresyon riski olan ve olmayan diyabet hastalarııın da karşılaştırmaktır amacııla tasarlanmıştır.

Gereç ve Yöntem: Tanımlayııı tipteki araştırma, Üniversite Hastanesi'nde Haziran 2016 - Eylül 2016 tarihleri arasında yapılmıştır. Araştırmanın örneklemini 200 hasta oluşturmuştur. Araştırmanın verileri; Tanıııı Bilgi Formu, Hastane Anksiyete ve Depresyon Ölçeği, Hastalık Algııı Öıçeği ile toplanmıştır. Verilerin değerlendirilmesinde, tanımlayııı istatistikler, t-testi, ki-kare ve korelasyon analizi kullanıımışır.

Bulgular: Araştırmada hastaların yaş ortalaması 54.74 $\pm 11.5, \% 62.5^{\prime}$ i kadın, \%64.5' i gelir durumunun kötü, \%87'si evli, \%43'ü ilköğretim mezunu, \%39'unun Diyabet dışında başka kronik hastalığı mevcut, \%66's Diyabete bağlı komplikasyonlar yaşamakta, \%22.5’ 11-20 yıldır Diyabet hastalığı mevcut ve \%73.5 Diyabet hastalığı hakkında yeterli bilgiye sahip olduğunu ifade etmiştir. Hastaların \%32'si anksiyete alt ölçeğinden, \%49'unun da depresyon alt ölçeğinden eşik üstü puan almışlardır. Anksiyete riski olan hastalarda hastalığı anlama, kişisel kontrol ve tedavi kontrol puanının anksiyete riski olmayan hastalara göre düşü̈k, emosyonel temsiller ve psikolojik atıflar puanının yüksek olduğu; depresyon riski olan hastalarda kişisel kontrol ve süre (döngüsel) puanının depresyon riski olmayan hastalara göre düşük, emosyonel temsiller puanının yüksek olduğu belirlenmiştir.

Sonuçlar: Diyabet hastalarıın $\% 32$ 'sinin anksiyete alt boyutunda, \%49'unun da depresyon alt boyutunda eşik üstü puan aldıkları ve bu hastaların hastalık algılarının negatif olduğu anlaşılmaktadır.

Anahtar sözcükler: Diyabet anksiyete, depresyon, hastalık algısı

\section{THE INFLUENCE/EFFECT OF THE DISEASE SYMPTOMS ON ANXIETY AND DEPRESSION SYMPTOMS IN DIABETIC PATIENTS}

\section{ABSTRACT}

Objectives: This study aims to determine the levels of anxiety and depression in diabetic patients (Type 1-2), and to compare diabetic patients with and without anxiety and depression risks of the disease perception???!.

Methods: The descriptive study was conducted between June 2016 and September 2016 at the Medical Center Hospital. Three forms were used as data collection tools. The sample of the study consisted of 200 patients. Data from the study; Introductory Information Form, Hospital Anxiety and Depression Scale, Disease Perception Scale. Data were analyzed using frequency distributions, Student's t-test, ANOVA, Pearson correlation and chi-square tests.

Results: In the study, the average age of the patients was $54.74 \pm 11.5,62.5 \%$ of them were women, $64.5 \%$ were in poor condition, $87 \%$ were married, $43 \%$ were primary school graduates, $39 \%$ had other chronic diseases except for diabetes, Diabetes has experienced complications???!, $22.5 \%$ have diabetes mellitus for $11-20$ years and $73.5 \%$ have enough knowledge about diabetes mellitus. Of the patients, $32 \%$ had an anxiety subscale, and $49 \%$ had a supra-threshold score on the depression subscale. In patients with anxiety risk, the understanding of the patient's perception of the disease, personal control and treatment control scores were lower than the anxiety non-risk patients, and the scores of emotional representation and psychological attributions were higher; Personal control and duration (cyclic) scores of depressed patients with depression were found to be lower than those without depression, and scores of emotional representations were higher.

Conclusions: It is understood that $32 \%$ of the diabetic patients have anxiety subscale, $49 \%$ of them have surprised points in the depression subscale and the disease perceptions of these patients are negative.

Keywords: Diabetes anxiety, depression, disease perception 
D iabetes Mellitus, pankreastan salgılanan beta hücrelerinin bozukluğu sonucu insülin hormonunun yetersizliği veya yokluğu nedeniyle hiperglisem ile karakterize, protein, karbonhidrat ve yağ metabolizmasında bozukluğa yol açan ve yaşam boyu devam eden metabolik bir hastalıktır $(1,2)$.

Diabetes mellitus (diyabet), hasta açısından ruhsal, duygusal, sosyal, psikoseksüel bir dizi sorun ve çatışmanın gündeme gelmesine yol açabilen, süreğen bir bedensel hastalıktır. Ruhsal durum diyabetin ortaya çıkış seyrinde etkili olduğu gibi, bir fiziksel hastalık olarak diyabet ve komplikasyonları da ruhsal durum üzerine etki ederler $(3,4,5)$. Emosyonel gerginlik hem nöroendokrin ve hormonal yollarla hem de dolaylı olarak diyabetin tedavi ve izlenmesini etkileyerek kan şekeri bozukluğuna yol açmaktadır $(3,4)$. Anksiyete ile epinefrin salgısının uyarıldığı ve bunun da insülin etkisini azalttığı bilinmektedir. En basit psikososyal zorlanma ve ruhsal çatışmada dahi serbest yağ asitleri, kortizol ve kan şekeri artmaktadır. Tıbbi tedaviye rağmen, kan şekeri düzenlenemeyen hastalarda stres ve kaygı önemli bir etkendir. Böyle durumlarda insülin dozunu artırmadan önce psikososyal değerlendirme yapılması çok önemlidir $(4,6)$. Diyabetik bir hastada ruhsal durum-kan şekeri ilişkisi ve etkileşimi şu şekilde özetlenebilir:

- Kan şekeri bozukluğu beyin işlevlerini bozarak organik beyin sendromuna neden olabilir.

- Psikososyal zorlanmalar ve ruhsal çatışmalar, kan şekerinde oynamalar yapabilir.

- Diyabet ruhsal bozukluk gelişimini tetikleyebilir.

- Ruhsal-davranışsal durum diyabetin seyrini, gidişini ve tedaviye yanıtını etkileyebilir.

- Diyabete, komplikasyonlarına ya da tedavi yöntemlerine bağlı olarak anksiyete, depresif mizaçlı uyum bozukluğu gelişebilir (4).

Uluslararası Diyabet Federasyon (The International Diabetes Federation) Diyabet Atlası tahminlerine göre 2015'te 11 yetişkinden bireyden 1'inin diyabet olduğu (415 milyon) 2 diyabetli yetişkinden 1'ine $(\% 46,5)$ teşhis konulmamış yani diyabetli olduğunu bilmedikleri gözlenmiş. Küresel sağlık harcamalarının \%12'si, diyabete harcandığı (673 milyar ABD Doları), 7 doğumdan 1'i gebelik diyabetinden etkilendiği tespit edilmiştir. Federasyonun tahminlerine göre diyabet 2040 'da, her 10 yetişkinden 1'inin diyabet hastası olacağı (642 milyon) ve Diyabet ile ilişkili hastalıkların sağlık harcamaları 802 milyon ABD dolarını aşacağı tahmin edilmiştir (7).
Diyabetli vakalarda, hastalık algısı ile anksiyete-depresyon düzeyi arasındaki ilişki hastalığın takip ve tedavisini etkileyen önemli faktörler olduğuna inanılmaktadır $(8,9,10,11)$. Hastalık algısı, hastalık durumunun bilişsel görünümü olarak tanımlanmaktadır. Bir hastalıkla karşı karşıya kalındığında hastalığı anlamak ve baş etmek için, insanlar kişisel deneyimleri, bilgileri, değerleri, inançları ve gereksinmeleri ışığında hastalıklarını açıklamaya çalışırlar; hastalıkla ilgili kendi modellerini ve temsillerini yaratırlar $(12,13)$.

Hastalar herhangi bir hastalık tanısı aldıklarında, genellikle kendi durumları hakkında çeşitli inanışlar geliştirirler. Bu inanışlar, hastalığın yönetimi için davranışın kilit noktalarını oluşturur. Hastalık hakkında hastaların algılarının ve fikirlerinin değişimi, tedaviye yanıtta da değişmeye yol açan dinamik bir süreçtir. Bu algı veya bilişsel süreçler, bireyin hastalığa verdiği duygusal yanıtı ve tedaviye uyumu gibi davranışları doğrudan etkiler. Bu doğrultuda diyabet gibi kronik hastalığı olan hastaların, hastalıkları ile ilgili sahip oldukları algılarının pozitif yönde değiştirilmesiyle, kendi kendini yönetebilmeleri, hastalığın oluşturduğu anksiyete ve depresyonla baş edebilmeleri ve hastalığa eşlik eden günlük stresin üstesinden gelebilmeleri için beceri kazandırılabilir gibi görünmektedir $(14,15)$.

Literatürde diyabet hastalarının (Tip I ve Tip II) hastalık algısı araştıran $(11,16)$ ve depresyon ve anksiyete durumlarını araştıran birçok araştırma vardır. Ancak hastalık algılarının, anksiyete ve depresyon belirtileri üzerine etkisini araştıran çok az sayıda çalışmaya rastlanmıştır (17-21,22). Hastalık algısının etkileyebilecek kültürel etkenler dikkate alındığında Türkiye'de konunun araştırılmaması da önemli bir eksikliktir. Bu doğrultuda çalışmamızdaki amacımız, diyabet hastalarının hastalık algılarını, anksiyete ve depresyon düzeyi belirlemek, anksiyete ile depresyon riski olan ve olmayan diyabet hastalarının hastalık algılarını karşılaştırmaktır.

\section{Gereç ve yöntem}

Araştırmanın tipi

Bu araştırma, tanımlayıcı olarak geliştirilmiştir.

Araştırmanın yeri ve zamanı

Araştırma bir Üniversite Hastanesi'nde Aralık 2017 - Şubat 2018 arasında yapılmıştır.

\section{Araştırmanın evreni ve örneklem seçimi}

Araştırmanın evrenini çalışmanın yapıldığı tarihler arasında bir Üniversite Hastanesi'nde diyabet tanısı ile yatarak tedavi gören en az bir yıldır diyabet tanısı olan 
hastalar oluşturmuştur. Araştırmada örneklem seçimine gidilmemiş araştırmaya katılmayı kabul eden hastalar araştırma kapsamına alınmış ve 200 hasta ile araştırma tamamlanmıştır.

\section{Hastaların araştırmaya alınma kriterleri}

- Psikiyatrik hikâyesi bulunmamak

- Iletişim kurabilen

- En az bir yıldır diyabet tanısı almış olmak

\section{Veri toplama araçları}

Araştırma verilerinin toplanmasında Anket Formu, Hastane Anksiyete ve Depresyon Ölçeği ve Hastalık Algısı Ölçeği (HAÖ) kullanılmıştır.

Tanıtıcı Bilgi Formu: Araştırmacı tarafından hazırlanan 12 maddelik anket formu hastaların sosyo-demografik özelliklerini ve hastalığa ait bilgilerini içermektedir.

\section{Hastane Anksiyete ve Depresyon Ölçeği-HAD (Hospital Anxiety and Depression Scale): Bedensel hastalığı olan} hastalar ve birinci basamak sağlık hizmetlerine başvuran gruba uygulanan ölçek, hastada anksiyete ve depresyon yönünden riski belirlemek ve şiddetini değerlendirmek amacıyla Zigmond ve Snaith tarafından geliştirilmiştir (23). Toplam 14 soru içermekte olup, bunların yedisi (tek sayılar) anksiyeteyi ve diğer yedisi (çift sayılar) depresyonu ölçmektedir. Dörtlü Likert tipi ölçüm sağlamaktadır. Türkçe geçerlilik ve güvenilirliği Aydemir tarafından yapılmış olan ölçeğin, bedensel hastalığı olanlarda depresyon ve anksiyete belirtilerini tarama açısından güvenilir olduğu saptanmıştır. Türkiye'de yapılan çalışma sonucunda anksiyete alt ölçeği için kesme puanı 10/11, depresyon alt ölçeği için ise 7/8 belirlenmiştir (24). Buna göre bu puanların üzerinde alanlar risk altında olarak değerlendirilirler. İki alt ölçekten de alınacak en düşük puan 0 , en yüksek puan 21 'dir. Türkiye'de yapılan geçerlilik güvenirlik çalışmasında; anksiyete alt ölçeği Cronbach alpha değeri 0.85, depresyon alt ölçeği Cronbach alpha değeri 0.77'dir (24). Bu çalışmada; anksiyete alt ölçeği Cronbach alpha değeri 0.82 , depresyon alt ölçeği Cronbach alpha değeri 0.78 saptanmıştır. Çalışmamızda HAD ölçeği bedensel belirtilere ilişkin madde içermemesi nedeniyle tercih edilmiştir.

\section{Hastalık Algısı Ölçeği (HAÖ)}

1996 yılında Weinmann tarafından geliştirilmiş ve 2002 yılında Moss-Morris ve arkadaşları tarafından gözden geçirilmiş̧ir $(25,26)$. Ölçeğin Türkçe uyarlaması ve geçerlilikgüvenilirlik çalışması, 2007 yılında Kocaman ve arkadaşları tarafından gerçekleştirilmiştir (14).
Ölçek üç boyuttan oluşmaktadır: Hastalık tipi, Hastalık hakkındaki görüşler, Hastalık nedenleri boyutları

Hastalık tipi boyutu: Sık görülen 14 hastalık belirtisini (ağrı, boğazda yanma, bulantı, soluk almada güçlük, kilo kaybı, yorgunluk, eklem sertliği, gözlerde yanma, hırıltılı soluma, baş ağrısı, mide yakınmaları, sersemlik hissi, uyku güçlüğü, güç kaybı) içerir. Bu belirtilerin her biri için kişiye önce, "hastalığın başlangıcından bu yana yaşayıp yaşamadığı", daha sonra "bu belirtiyi hastalığıyla ilgili görüp görmediği" sorulur. Bu boyut, her belirti için iki soruya da evet/hayır biçiminde yanıt verilecek biçimde düzenlenmiştir. İkinci sorudaki evet yanıtlarının toplamı hastalık tipi boyutunun değerlendirme sonucunu oluşturur.

Hastalık Hakkındaki Görüşleri Boyutu: 38 maddeden oluşmakta ve 7 alt boyutu içermektedir. Bunlar "süre (akutkronik) sonuçlar, kişisel kontrol, tedavi kontrolü, hastalığı anlayabilme, süre (döngüsel) ve duygusal temsiller" olarak isimlendirilmiştir. Ölçeğin süre alt boyutu, kişinin hastalığının süresiyle ilgili algılarını araştırır ve akut, kronik olarak algılandığını gösterir. Sonuçlar alt ölçeği, kişinin hastalığının şiddetine, fiziksel, sosyal ve psikolojik işlevselliğine olası etkileriyle ilgili inançlarını araştıırı. Sonuçlar alt boyutu yüksek puanı, hastanın hastalığın negatif sonuçlarına olan inancının yüksek olduğunu gösterir. Kişisel kontrol, kişinin hastalığının süresi, seyri ve tedavisi üzerindeki iç kontrol algııını araştırır. Tedavi kontrolü kişinin, uygulanan tedavinin etkinliği hakkındaki inançlarını araştırır. Yüksek puanlar, hastanın hastalığı ve tedaviyi kontrol edebildiği hakkında pozitif inançlara sahip olduğunu gösterir. Hastalığı anlayabilme, kişinin hastalığını ne kadar anladığını ya da kavradığını araştıırı. Yüksek puan, durumun kişisel olarak anlaşılabilirliğinin yüksek olduğunu gösterir. Duygusal temsiller, kişinin hastalığıyla ilgili hissettiklerini araştırır. Yüksek puan, hastalıkla provoke olan duygusal etkinin ve negatif duyguların yüksek olduğunu gösterir.

Hastalık nedenleri boyutları: Nedenler boyutunda; "kesinlikle böyle düşünmüyorum" (1) "kesinlikle böyle düşünüyorum"(5) arasında değerlendirilen 5li likert tipi 18 maddeden oluşmaktadır. Bu bölüm 5 alt ölçek içermektedir. Bu alt ölçekler, Kişisel Atıflar, Dış Atıflar, Yaşam Şekli Atıfları, Kontrol Edilemeyen Bedensel Atıflar ve Şans'tır. Alt ölçeklerin içerikleri ise şu şekildedir. Kişisel Atıflar alt ölçeği, kişilerin hastalık nedenini stres ya da endişeye, kendi tutumuna, kişilik özelliklerine, duygusal durumuna, aile problemlerine, vücut direncinin azalmasına, kendi davranışı gibi faktörlere bağlama düzeyini; Dış Atıflar alt ölçeği, kişilerin hastalık nedenini geçmişindeki kötü tıbbi bakıma, çevre kirliliğine, kaza ya da 
yaralanmaya, aşırı çalışmaya ve benzeri faktörlere bağlama düzeyini; Yaşam Şekli Atıfları alt ölçeği, kişilerin hastalık nedenini sigara içmeye, alkole, diyet yemek alışkanlıkları gibi faktörlere bağlama düzeyini; Kontrol Edilemeyen Bedensel Atıflar alt ölçeği, kişilerin hastalık nedenini bir mikrop ya da virüse, kalıtsallık, yaşlanma gibi faktörlere bağlama düzeyini; Şans alt ölçeği, kişilerin hastalık nedenini şans ya da kötü talih gibi faktörlere bağlama düzeyini göstermektedir. Ölçeğin Türkçe geçerlik ve güvenirlik çalışmasında hastanın hastalık hakkında görüşlerini içeren boyutun alt ölçeklerinin alfa katsayılarının 0.69-0.77 arasında ve hastalık nedenlerinin alt ölçeklerinin alfa güvenirlik katsayılarının 0.25-0.72 arasında değiştiği belirlenmiştir (14). Bu çalışmada hastalık hakkında görüşleri boyutunun Cronbach alpha değeri 0.620.87 arasında ve hastalık nedenleri alt boyutunun Cronbach alpha değeri 0.55-0. 67 arasında değiştiği saptanmıştır.

\section{Verilerin istatistiksel değerlendirilmesi}

Araştırma verileri SPSS 15.0 programında değerlendirilmiştir. Ölçümle belirtilen verilerin değerlendirmesinde tanımlayıcı istatistiksel yöntemlerin (frekans, ortalama, standart sapma) yanı sıra, parametrik test varsayımları karşılandığı için iki grubun karşılaştırılmasında bağımsız t-testi ve ANOVA uygulanmıştır. Sürekli değişkenler arasındaki ilişki için Pearson korelasyon analizi, nitel verilerin karşılaştırılmasında ki-kare testi kullanılmıştır. Sonuçlar $p<0.05$ anlamlılık düzeyinde değerlendirilmiştir.

\section{Araştırmanın etik ilkeleri}

Araştırmanın yapılabilmesi için klinik araştırmalar Etik Kurulundan etik onay alınmıştır (2018/1-11). Çalışmaya başlamadan önce bir Üniversite Hastanesi Başhekimliğinden yazılı izin alınmıştır. Veri toplama formu doldurulmadan önce hastalara çalışmaya katılıp katılmama konusunda özgür oldukları açıklanarak sözel onamları alınmış ve istedikleri zaman araştırmadan çekilebilecekleri belirtilmiştir.

\section{Bulgular}

Diyabet hastalarının demografik özelliklerine baktığımızda; hastaların yaş ortalaması 54.74 $\pm 11.5, \% 62.5^{\prime} \mathrm{i}$ kadın, \%79'u çalışmıyor, \%64.5'i gelir durumunun kötü, \%27.5'inin gelir durumu orta, \%87'si evli, \%87 çekirdek aile yapısına sahip, \%43'ü ilköğretim mezunu, \%30'u okuryazar olmadığını ifade etmiştir. Diyabet hastalığı ile ilgili özelliklere baktığımızda; hastaların \%39'unun Diyabet dışında başka kronik hastalığı mevcut, \%66'sı Diyabete bağlı komplikasyonlar yaşamakta, \%35'i 1-5 yıldır Diyabet hastalığı mevcut iken \%22.5'i 11-20 yıldır Diyabet hastalığı mevcut ve \%73.5 Diyabet hastalığı hakkında yeterli bilgiye sahip olduğunu ifade etmiştir (Tablo 1).
Tablo 1. Tanitıcı özellikler

\begin{tabular}{|c|c|c|}
\hline Demografik Özellikler & Sayı & $\%$ \\
\hline $\begin{array}{l}\text { Yaş grubu } \\
26-35 \\
36-45 \\
46-55 \\
56-65 \\
66-75\end{array}$ & $\begin{array}{l}11 \\
21 \\
74 \\
57 \\
37\end{array}$ & $\begin{array}{c}5.5 \\
10.5 \\
37.0 \\
28.5 \\
18.5\end{array}$ \\
\hline $\begin{array}{l}\text { Cinsiyet } \\
\text { Kadın } \\
\text { Erkek }\end{array}$ & $\begin{array}{c}125 \\
75\end{array}$ & $\begin{array}{l}62.5 \\
37.5\end{array}$ \\
\hline $\begin{array}{l}\text { Çalışma durumu } \\
\text { Çalışıyor } \\
\text { Çalışmıyor }\end{array}$ & $\begin{array}{c}42 \\
158\end{array}$ & $\begin{array}{l}21.0 \\
79.0\end{array}$ \\
\hline $\begin{array}{l}\text { Gelir durumu } \\
\text { Kötü } \\
\text { Orta } \\
\text { İyi }\end{array}$ & $\begin{array}{l}129 \\
55 \\
16\end{array}$ & $\begin{array}{c}64.5 \\
27.5 \\
8.0\end{array}$ \\
\hline $\begin{array}{l}\text { Medeni durum } \\
\text { Evli } \\
\text { Bekâr }\end{array}$ & $\begin{array}{c}174 \\
26\end{array}$ & $\begin{array}{l}87.0 \\
13.0\end{array}$ \\
\hline $\begin{array}{l}\text { Aile tipi } \\
\text { Çekirdek } \\
\text { Geniş } \\
\text { Parçalanmış }\end{array}$ & $\begin{array}{c}352 \\
15 \\
34\end{array}$ & $\begin{array}{l}87.0 \\
3.7 \\
8.5\end{array}$ \\
\hline $\begin{array}{l}\text { Eğitim durum } \\
\text { Okuryazar değil } \\
\text { Okuryazar } \\
\text { Illkögrretim } \\
\text { Lise } \\
\text { Üniversite }\end{array}$ & $\begin{array}{l}60 \\
19 \\
86 \\
23 \\
12\end{array}$ & $\begin{array}{c}30.0 \\
9.5 \\
43.0 \\
11.5 \\
6.0\end{array}$ \\
\hline $\begin{array}{l}\text { Başka kronik hastalık } \\
\text { Var } \\
\text { Yok }\end{array}$ & $\begin{array}{c}79 \\
121\end{array}$ & $\begin{array}{l}39.5 \\
60.5\end{array}$ \\
\hline $\begin{array}{l}\text { Diyabet komplikasyonu } \\
\text { Var } \\
\text { Yok }\end{array}$ & $\begin{array}{c}68 \\
132\end{array}$ & $\begin{array}{l}34.0 \\
66.0\end{array}$ \\
\hline $\begin{array}{l}\text { Hastalık süresi } \\
1-5 \text { yıl } \\
6-10 \text { yıl } \\
11-20 \text { yıl } \\
21 \text { ve üstü }\end{array}$ & $\begin{array}{l}70 \\
60 \\
45 \\
21\end{array}$ & $\begin{array}{c}35 \\
30 \\
22.5 \\
10.5\end{array}$ \\
\hline
\end{tabular}

Tablo 2'de hastaların HAÖ 'nin alt boyutları incelendiğinde; kişisel kontrol algısı alt boyutunun ortalaması 18.97 \pm 3.2 , süre (akut/kronik) algısı alt boyutunun ortalaması $22.66 \pm 5.8$, duygusal temsiller algısı alt boyutunun ortalaması 22.37 \pm 6.0 , hastalığı anlayabilme algısı alt boyutunun ortalaması $16.30 \pm 4.8$, sonuçlar algısı alt boyutunun ortalaması $20.41 \pm 4.6$, tedavi kontrolü algısı alt boyutunun ortalaması $17.74 \pm 3.3$ ve süre (döngüsel) algısı alt boyutunun ortalaması $14.78 \pm 2.9$ 'dur. Hastalık nedenleri boyutunun alt boyutları incelendiğinde; psikolojik atıflar alt boyutunun ortalamasının $17.65 \pm 4.3$, risk nedenleri alt boyutunun ortalamasının $16.57 \pm 6.3$, bağışıklık alt boyutunun ortalamasının 2.2 \pm 5.9 , kaza veya şans alt boyutunun ortalamasının 
ise $4.3 \pm 1.7$ olduğu görülmektedir (Tablo 2). Diyabetli hastaların HAD ölçeğinden aldıkları puanlara bakıldığında anksiyete alt boyut ortalaması $8.85 \pm 0.46$ ile eşik altında kaldığı yine depresyon alt boyut puan ortalamasının da $7.63 \pm 0.59$ ile eşik altında kaldığı görülmektedir. HAD'in anksiyete ve depresyon alt boyutlarında aldıkları puanlar eşik altı ve eşik üstü olarak değerlendirildiğinde, hastaların \%32'sinin anksiyete alt boyutunda, $\% 49$ 'unun da depresyon alt boyutunda eşik üstü puan aldıkları görülmektedir. Bununla birlikte anksiyete alt boyutunda eşik altı puan alan hastaların oranı $\% 68$ iken depresyon alt boyutundan eşik altı puan alan hastaların oranı ise \%51'dir (Tablo 2).

Diyabet hastalarının HAÖ'i hastalık belirtileri bölümü bulgularının dağılımı Tablo 3'te verilmiştir. Buna göre araştırmaya katılan hastaların en fazla yorgunluk yaşadıkları $(\% 79,5)$ ve bu belirtinin büyük oranda $(\% 69,5)$ hastalıkla ilgili olduğunu düşündükleri görülmüştür. Bu belirtiyi $\% 65,5$ oranındaki hastanın hastalıklarıyla ilgili gördükleri, güç kaybı $(\% 69,5)$ ve \%33'ünün hastanın hastalıklarıyla ilgili bulduğu ağrı (\%57) olarak saptanmıştır. Hastalık başlangıcından sonra en düşük düzeyde bildirilen belirti ise hırıltılı soluma $(\% 19,0)$ olmuştur. Bu belirtiyi hastalıkla ilgili görenlerin oranı ise daha da düşüktür $(\% 6,0)$ (Tablo 3).

Anksiyete ve depresyon riski olan Diyabet hastalarıyla olmayanların HAÖ’nün alt boyutlarına göre kıyaslandığında; anksiyete riski (anksiyete puanı 11 ve $\uparrow$ ) olan hastalarda kişisel kontrol alt boyut puanı 17.6 \pm 3.7 , risk olmayan (Anksiyete 10 ve $\downarrow$ ) hastalardaki puan $19.7 \pm 4.8$ olduğu ve aralarındaki farkın istatistiksel olarak anlamlı olduğu saptanmıştır $(p<0.05)$. Anksiyete riski olan hastalarda duygusal temsiller alt boyut puanı $22.5 \pm 5.8$, riski olmayan hastalardaki puan $19.5 \pm 4.3$ olduğu ve aralarındaki farkın istatistiksel olarak anlamlı olduğu saptanmıştır $(p<0.05)$. Anksiyete riski olan hastalarda hastalığı anlama alt boyut puanı $14.2 \pm 3.8$, riski olmayan hastalardaki puan $18.8 \pm 4.7$ olduğu ve aralarındaki farkın istatistiksel olarak anlamlı olduğu saptanmıştır $(p<0.05)$. Anksiyete riski olan hastalarda tedavi kontrol alt boyut puanı $15.6 \pm 3.2$, riski olmayan hastalardaki puan $17.9 \pm 4.2$ olduğu ve aralarındaki farkın istatistiksel olarak anlamlı olduğu saptanmıştır $(p<0.05)$. Anksiyete riski olan hastalarda psikolojik atıflar alt boyut puanı $18.8 \pm 4.6$, riski olmayan hastalardaki puan $16.0 \pm 3.8$ olduğu ve aralarındaki farkın istatistiksel olarak anlamlı olduğu saptanmıştır $(p<0.05)$.

Depresyon riski (Depresyon 8 ve $\uparrow$ ) olan hastalarda kişisel kontrol puanı 17.5 \pm 4.1 , risk olmayan (Depresyon 7 ve $\downarrow$ ) kişisel kontrol alt boyut puanı $17.6 \pm 3.7$, risk olmayan
Tabıo 2. Hastaların Hastalık Algısı ÖIçeği'nin alt boyutlarının iç tutarllllk katsaylları ve betimleyici istatistikleri

\begin{tabular}{|c|c|c|c|}
\hline HAÖ & $X \pm S S$ & Min & Max \\
\hline $\begin{array}{l}\text { Hastalık Hakkındaki Görüşler Boyutu } \\
\text { Kişisel kontrol boyutu }\end{array}$ & $18.97 \pm 3.2$ & 10 & 25 \\
\hline Süre akut /kronik boyutu & $22.66 \pm 5.8$ & 7 & 30 \\
\hline Duygusal temsiller & $22.37 \pm 6.0$ & 6 & 30 \\
\hline Hastalığı anlayabilme & $16.30 \pm 4.8$ & 5 & 25 \\
\hline Sonuçlar & $20.41 \pm 4.6$ & 7 & 30 \\
\hline Tedavi kontrol & $17.74 \pm 3.3$ & 7 & 25 \\
\hline Süre (Döngüsel) & $14.78 \pm 2.9$ & 4 & 20 \\
\hline $\begin{array}{l}\text { Hastalık Nedenleri } \\
\text { Psikolojik Atıflar }\end{array}$ & $17.65 \pm 4.3$ & 6 & 30 \\
\hline Risk Etkenleri & $16.57 \pm 6.3$ & 7 & 31 \\
\hline Bağışıklık & $2.2 \pm 5.9$ & 3 & 13 \\
\hline Kaza veya şans & $4.3 \pm 1.7$ & 2 & 10 \\
\hline $\begin{array}{l}\text { HAD } \\
\text { HAD-A } \\
\text { Eşik altı (0-10 puan) } \\
\text { Eşik üstü (11 puan üstü) }\end{array}$ & $8.85 \pm 0.46$ & 0 & 21 \\
\hline $\begin{array}{l}\text { HAD-D } \\
\text { Eşik altı (0-8 Puan) } \\
\text { Eşik üstü (9 puan üstü) }\end{array}$ & $7.72 \pm 0.59$ & 0 & 19 \\
\hline
\end{tabular}

Tablo 3.Hastalık Algısı Ölçeği, Belirtiler bölümü işaretlenme oranları.

\begin{tabular}{lcc} 
Belirtiler & $\begin{array}{c}\text { Hastalık başlangıcından } \\
\text { sonra belirti yaşayanlar } \\
\text { (\%) }\end{array}$ & $\begin{array}{c}\text { Belirtiyi hastalığıyla } \\
\text { ilgili görenler } \\
\text { (\%) }\end{array}$ \\
\hline Yorgunluk & 79.5 & 69.5 \\
Güç kaybı & 69.5 & 65.5 \\
Ağrı & 57.0 & 33.0 \\
Bulantı & 33.0 & 10.0 \\
Uyku güçlüğü & 48.5 & 33.0 \\
Mide yakınmaları & 37.0 & 17.0 \\
Sersemlik hissi & 50.5 & 33.5 \\
Bağ ağrlları & 60.5 & 36.5 \\
Kilo kaybı & 47.5 & 32.5 \\
Eklem sertliği & 24.5 & 17.5 \\
Boğazda yanma & 22.0 & 10.0 \\
Soluk almada güçlük & 26.0 & 14.5 \\
Gözlerde yanma & 36.5 & 22.5 \\
Hırıttılı soluma & 19.0 & 6.0
\end{tabular}

(Anksiyete 10 ve $\downarrow$ ) hastalardaki puan $20.1 \pm 4.6$ olduğu ve aralarındaki farkın istatistiksel olarak anlamlı olduğu saptanmıştır $(p<0.05)$. Depresyon riski olan hastalarda duygusal temsiller alt boyut puanı $21.9 \pm 4.6$, riski olmayan 
Tablo 4. Anksiyete ve depresyon riskine göre hastaların hastalık algısının karşılaştıııması

\begin{tabular}{|c|c|c|c|c|c|c|c|c|c|}
\hline HAÖ & $X \pm S S$ & Anksiyete 11 ve $\uparrow$ & Anksiyete 10 ve $\downarrow$ & $t$ & $p$ & Depresyon 8 ve $\uparrow$ & Depresyon 7 ve $\downarrow$ & $t$ & $p$ \\
\hline \multicolumn{10}{|l|}{$\begin{array}{l}\text { Hastalık Hakkındaki } \\
\text { Görüşler Boyutu }\end{array}$} \\
\hline Kişisel kontrol boyutu & $18.9 \pm 3.2$ & $17.6 \pm 3.7$ & $19.7 \pm 4.8$ & -1.76 & 0.02 & $17.5 \pm 4.1$ & $20.1 \pm 4.6$ & 2.03 & 0.01 \\
\hline Süre akut/kronik boyutu & $22.6 \pm 5.8$ & $22.9 \pm 5.3$ & $21.8 \pm 4.9$ & -1.21 & $>0.05$ & $22.8 \pm 5.6$ & $21.6 \pm 5.2$ & 1.06 & $>0.05$ \\
\hline Duygusal temsiller & $22.3 \pm 6.0$ & $22.5 \pm 5.8$ & $19.5 \pm 4.3$ & -2.82 & 0.001 & $21.9 \pm 4.6$ & $19.1 \pm 4.4$ & -1.96 & 0.02 \\
\hline Hastalığı anlayabilme & $17.3 \pm 4.8$ & $14.2 \pm 3.8$ & $18.8 \pm 4.7$ & 3.25 & 0.001 & $17.5 \pm 4.9$ & $18.0 \pm 4.1$ & 0.72 & $>0.05$ \\
\hline Sonuçlar & $20.4 \pm 4.6$ & $22.2 \pm 3.5$ & $20.3 \pm 3.8$ & -1.66 & $>0.05$ & $21.8 \pm 3.7$ & $20.9 \pm 4.9$ & -1.26 & $>0.05$ \\
\hline Tedavi kontrol & $17.7 \pm 3.3$ & $15.6 \pm 3.2$ & $17.9 \pm 4.2$ & 1.32 & 0.01 & $15.7 \pm 3.3$ & $16.7 \pm 3.9$ & 0.88 & $>0.05$ \\
\hline Süre (Döngüsel) & $13.7 \pm 2.9$ & $13.8 \pm 4.3$ & $14.2 \pm 3.2$ & -0.76 & $>0.05$ & $13.3 \pm 3.0$ & $14.7 \pm 4.4$ & -1.07 & 0.02 \\
\hline \multicolumn{10}{|l|}{ Hastalık Nedenleri } \\
\hline Psikolojik Atıflar & $17.6 \pm 4.3$ & $18.8 \pm 4.6$ & $16.0 \pm 3.8$ & 1.00 & 0.01 & $18.6 \pm 4.4$ & $17.8 \pm 5.3$ & 1.43 & $>0.05$ \\
\hline Risk Etkenleri & $16.5 \pm 6.3$ & $16.8 \pm 5.7$ & $16.1 \pm 4.2$ & -0.79 & $>0.05$ & $16.3 \pm 5.7$ & $15.8 \pm 4.2$ & 0.79 & $>0.05$ \\
\hline Bağışıklık & $2.2 \pm 5.9$ & $2.3 \pm 4.9$ & $2.0 \pm 4.5$ & -1.33 & $>0.05$ & $2.0 \pm 3.7$ & $1.9 \pm 3.3$ & -2.32 & $>0.05$ \\
\hline Kaza veya şans & $4.3 \pm 1.7$ & $4.4 \pm 2.9$ & $3.9 \pm 2.2$ & -0.02 & $>0.05$ & $3.8 \pm 2.3$ & $3.5 \pm 1.9$ & 3.01 & $>0.05$ \\
\hline
\end{tabular}

hastalardaki puan $19.1 \pm 4.4$ olduğu ve aralarındaki farkın istatistiksel olarak anlamlı olduğu saptanmıştır ( $p<0.05)$. Depresyon riski olan hastalarda süre (döngüsel) alt boyut puanı 13.3 \pm 3.0 , riski olmayan hastalardaki puan $14.7 \pm 4.4$ olduğu ve aralarındaki farkın istatistiksel olarak anlamlı olduğu saptanmıştır $(p<0.05)$ (Tablo 4).

\section{Tartışma}

Diyabetes mellitusla en sık birlikte görülen psikiyatrik durumlar anksiyete ve depresyondur. Diyabetli hastalarda depresyon, genel nüfusa göre daha yüksek oranda görülmektedir. Diyabete eşlik eden depresyon, hastanın uyumunu, yaşam kalitesini, tedaviye yanıtı, prognozu, diyabetin gidişini, mortalite ve morbiditeyi olumsuz etkilemekte; diyabetin kontrol altına alınmasını güçleştirmektedir $(4,27,28)$.

Araştırmada diyabet hastalarının Hastalık Algısı Ölçeğinden aldıkları puan ortalamalarına göre, alt boyutlarından en yüksek puanı Süre (Akut/Kronik) boyutu, en düşük puanı ise Bağışıklık boyutu aldığı belirlenmiştir (Tablo 2). Acehan'ın (2010) hipertansiyonlu hastalar üzerinde yaptığı benzer bir çalışmada hastaların, en yüksek puanı Süre (Akut/Kronik) boyutu, en düşük puanı ise Süre (Döngüsel) boyutu almıştır (29). Kayacan'ın (2012) kronik hastalıklarda hastalık algısını ve etkileyen faktörleri içerdiği araştırmasında hastaların, en yüksek puanı Kişisel Kontrol, en düşük puanı ise Süre (Döngüsel) alt boyutu bulunmuştur (30). Kayış'ın (2009) kanser hastaları üzerinde yaptığı araştırmada ise en yüksek puanı Kişisel Kontrol, en düşük puanı ise Süre (Döngüsel) boyutunun aldığı belirlenmiştir (31). Akgüç'ün diyabet hastaları üzerinde yaptığı çalışmada alt boyutlarından en yüksek puanı Süre (Akut/Kronik) boyutu, en düşük puanı ise Süre (Döngüsel) boyutu aldığı belirlenmiştir (32). Diyabet hastalarında hastalık algısının çalışıldığı diğer araştırmalar incelendiğinde; Akkoyunlu ve Akın'nın DM'li hastalarda yaptığı çalışmada Süre (akut/kronik) algısı ortalaması en yüksek, Süre (döngüsel) algısı ortalaması en düşük bulunmuştur $(22,33)$. Abubakari ve ark.'In tip II DM'li hastalarda yaptığı çalışmada ise kişisel kontrol algısı ortalaması en yüksek, süre (döngüsel) algısı ortalaması en düşük bulunmuştur (34). Aflakseir'in tip II DM'li hastalarda yaptığı çalışmada da kişisel kontrol algısı ortalaması en yüksek, süre (döngüsel) algısı ortalaması en düşük bulunmuştur (35). Araştırmamızdaki sonuçlarnın literatürdeki çalışmalarla hem paralel olduğu hemde farklılıklar gösterdiği görülmektedir. Bu farklı sonuçların farklı hasta gruplarında ve farklı kültürel özelliklerinden kaynaklandığı düşünülmektedir.

Araştırmada Diyabetli hastaların HAD ölçeği anksiyete ve depresyon alt boyut puan ortalamalarının eşik değerin altında kaldığı gözlenmiştir. Ayrıca hastaların \%32'sinin anksiyete alt boyutunda, \%49'unun da depresyon alt boyutunda eşik üstü puan aldıkları görülmektedir. Bununla birlikte anksiyete alt boyutunda eşik altı puan alan hastaların oranı \%68 iken depresyon alt boyutundan eşik altı puan alan hastaların oranı ise \%51'dir (Tablo 2). Turhan'ın çalışmasında; DM'lu hastaların HAD ölçeği anksiyete ve depresyon alt boyut puan ortalamalarının eşik değerin altında kaldığı saptanmıştır. Aynı çalışmada hastaların \%33'ünün anksiyete alt ölçeğinden, \%40'ının da depresyon alt 
ölçeğinden eşik üstü puan aldıkları görülmektedir (19). Bahar ve ark. çalışmasında hastaların \%30.8'inin anksiyete alt ölçeğinden, \%51.1'inin depresyon alt ölçeğinden eşik üstü puan almışlardır (21). Tav ve ark. yaptığı çalışmada HAD ölçeği anksiyete alt boyut puan ortalamalarının eşik değerin altında olduğu, depresyon alt boyut puan ortalamasının ise eşik üstü puan olduğu saptanmıştır. Collins et al. çalışmasında diyabet hastalarının \%32'sinin anksiyete alt boyutunda \%22.4'ünün de depresyon alt boyutunda eşik üstü puan aldıklarını belirtmiştir (18). Sönmez'in yaptığı çalışmada ise; diyabet hastalarının \%21.8'i anksiyete alt ölçeğinden, \%42'inin depresyon alt ölçeğinden eşik üstü puan almışlardır (21). Literatürdeki birçok çalışmada diyabet ile birlikte anksiyete ve depresyon gibi psikiyatrik rahatsızlıkların eşlik ettiği saptanmıştır. Çalışmalarda hastalarının \%14-40 arasında değişen düzeylerde anksiyete yaşadığı, \%10- 47.7 arasında değişen düzeylerde de depresyon belirtilerinin görüldüğü saptanmıştır. Bu sonuçlar araştırmamızın bulgularıyla paralellik göstermektedir $(18,19,20,21,36,37)$. Diyabet hastalarının Hastalık Algısı Ölçeği'nin "Belirtiler" alt boyutunda elde edilen sonuçlara göre, hastaların çoğunluğunun hastalıkları ile ilgili semptomlar yaşadıklarını ifade etmişlerdir. Hastalar bu semptomların, hastalıklarıyla ilgili olduğunu, fiziksel, sosyal ve psikolojik işlevlerine hastalığın etkisi olduğunu belirtmişlerdir. Araştırmada hastaların hastalığının başlangıcından bu yana en sık yaşadıkları belirtilerin sırasıyla, yorgunluk, güç kaybı, baş ağrısı, ağrı, sersemlik hissi, kilo kaybı gibi belirtiler izlemiştir (Tablo 3). Literatürdeki çalışmada belirtilerin sıralaması değişse de ortak belirtilerin görüldüğü saptanmıştır $(16,19,38)$. Bu sonuçlara göre; diyabet hastalarında, hastalığın belirtilerinin yanısıra komplikasyonların ve uygulanan tedavilerin oluşturduğu sıkıntı, gelecekte bakıma muhtaç olma kaygısı, hastanın kendi kendine yetme becerisini kaybedeceği, beden imajıyla ilgili organ ve işlev kaybı korkuları bireylerin fiziksel ve ruhsal birçok sorunu ortaya çıkmasına neden olmuş olabilir.

Araştırmada; anksiyete riski olan hastalarda kişisel kontrol boyutu düşük, hastalığı anlama puanının düşük, duygusal temsiller puanının yüksek ve psikolojik atıflar puanı

\section{Kaynaklar}

1. Yenigün M. Her Yönüyle Diabetes Mellitus, 2. Baskı. Nobel Tıp Kitabevi; 2001. pp.51-61, 63-7, 69-81, 215-7, 237-43.

2. Braunwald E, Fauci AS, Kasper DL, Hauser SL, Longo DL, Jameson JL. Harrison's Principles of Internal Medicine, 15th ed. US: McGraw-Hill; 2001. pp.2109-43.

3. Garret C, Doherty A. Diabetes and Mental Health. Clin Med 2014;14:669-72. [CrossRef] yüksek olduğu saptanmıştır. Depresyon riski olan hastalarda kişisel kontrol puanının düşük, süre (döngüsel) ve duygusal temsiller puanının yüksek olduğu aralarında istatistiksel olarak anlamlı bir ilişki saptanmıştır (Tablo 4). Literatürdeki bir çalışmada, diyabet hastalarının depresyon ile algılanan kontrol arasında ilişki olduğu gösterilmiştir (32). Akkoyunlu'nun çalışmasında; diyabet hastalarının depresyon ve anksiyete düzeyleri ile HAÖ duygusal temsiller alt ölçek puanları arasında ilişki olduğunu saptanmıştır (22). Akın'ın diyabet hastalarında HAD ölçeği ile HAÖ alt boyutları arasındaki ilişkiyi incelediği çalışmasında; HADÖ ile hastalık algısı ölçeğinin sonuçlar alt boyutu, tedavi kontrolü, hastalığı anlayabilme, süre (döngüsel), duygusal temsiller, risk etkenleri arasında istatistik olarak anlamlı bir ilişki saptanmıştır (33). Diyabet hastalarının değerlendirildiği başka bir çalışmada, anksiyete ve depresyon skorlarının HAÖ sonuçlar, kişisel ve tedavi kontrol alt boyutları ile anlamlı ilişki gösterdiği belirlenmiştir (39).

\section{Sonuç}

- Diyabet hastaların \%32'sinin anksiyete alt boyutunda, $\% 49$ 'unun da depresyon alt boyutunda eşik üstü puan aldıkları gözlenmiştir.

- Araştırmaya katılan hastalar diyabete bağlı olarak en çok yorgunluk, güç kaybı ve baş ağrısı şikayetleri yaşadıklarını ifade etmiş̧ir.

- Anksiyete riski olan hastalarda hastalığı anlama, kişisel kontrol ve tedavi kontrol puanını düşük, emosyonel temsiller ve psikolojik atıflar puanının yüksek olduğu saptandı. Depresyon riski olan hastalarda kişisel kontrol ve süre (döngüsel) puanının düşük, emosyonel temsiller puanının yüksek olduğu saptanmıştır.

Bu sonuçlar doğrultusunda; hastaların farkındalığın yaratılması amacıyla, diyabet tanısı almış hastalara belirli aralıklarla anksiyete ve depresyon yönünden değerlendirilmesi ve düzenli olarak yürütülecek psiko-eğitim ile destek verilmesi sağlanmalıdır. Araştırmamızın sonuçları, bir hastaneyi temsil etmesi nedeniyle sınırlılık göstermektedir. Bununla birlikte sonuçlarımızın bu konuda yapılacak çalışmalarda yararlı olacağını ümit ediyoruz. Gelecekteki çalışmalarda daha geniş bir evrende yapılması önerilmektedir.

4. Özkan S. Psikiyatrik Tıp: Konsultasyon Liyezon Psikiyatrisi, 1. Baskı. İstanbul: Roche Yayınları; 1993. pp.94-9.

5. Pearce MJ, Pereira K, Davis E. The psychological impact of diabetes: a practical guide for the nurse practitioner. J Am Assoc Nurse Pract 2013;25:578-83. [CrossRef]

6. Anderson RJ, Grigsby AB, Freedland KE, De Groot M, McGill JB, Clouse RE, Lustman PJ. Anxiety and poor glycemic control: a metaanalytic review of the literature. Int J Psychiatry Med 2002;32:23547. [CrossRef] 
7. IDF Diabetes Atlas - 8th ed. http://www.diabetesatlas.org Erişim tarihi: 30.05.2017.

8. Ponzo MG, Gucciardi E, Weiland M, Masi R, Lee R, Grace L. Gender, Ethnocultural, and Psychosocial Barriers to Diabetes SelfManagement in Italien Women and Men With Type 2 Diabetes. Behav Med 2006;31:153-60. [CrossRef]

9. Law GU, Kelly TP, Huey D, Summerbell C. Self-management and well-being in adolescents with diabetes mellitus: Do illness respresentations play a regulatory role. J Adolesc Health 2002;31:3815. [CrossRef]

10. Paschalides C, Wearden AJ, Dunkerley R, Bundy C, Davies R, Dickens $\mathrm{CM}$. The associations of anxiety, depression and personal illness representations with glycaemic control and health-related quality of life in patients with type 2 diabetes mellitus. J Psychosomatic Res 2004;57:557-64. [CrossRef]

11. Gündüz F, Yılmaz Karabulutlu E. Tip II Diyabetes Mellituslu Hastalarda Hastalık Algısı, Psikososyal Uyum Ve Glisemik Kontrolün Değerlendirilmesi. J Anat Nurs Health Sci 2016;19:106-15. Erişim: https://dergipark.org.tr/download/article-file/224257

12. Weinman J, Petrie KJ, Moss-Morris R, Horne R. The Illness Perception Questionnaire: A new method for assessing the cognitive representation of illness. Psychol Health 1996;11:431-45. [CrossRef]

13. Leventhal $H$, Leventhal EA, Contrada RJ. Self-regulation, health and behaviour: A perceptual cognitive approach. Psychol Health 1989;13:717-34. [CrossRef]

14. Kocaman N, Özkan M, Armay Z, Özkan S. Hastalık Algısı Ölçeğinin Türkçe uyarlamasının geçerlilik ve güvenilirlik çalışması. Anadolu Psikiyatri Derg 2007;8:271-80. Erişim: https://toad.halileksi.net/ sites/default/files/pdf/hastalik-algisi-olcegi-toad.pdf

15. Chilcot J. The Importance of Illness Perception in End-Stage Renal Disease: Associations with Psychosocial and Clinical Outcomes. Semin Dial 2012;25:59-64. [CrossRef]

16. Yorulmaz H, Tatar A, Saltukoğlu G, Soylu G. Diyabetli Hastalarda Hastalık Algısını Etkileyen Faktörlerin İncelenmesi. FSM İlmi Araș İnsan ve Toplum Bilim Derg 2013;2:36787. Erişim: https://pdfs.semanticscholar.org/d7fe/ ab2f2f22a4988233521c562e3cd445221883.pdf

17. Tav AŞ, Özenli Y, Ünsal A, Özşahin AK. Tip 2 diabetes mellitus ve obez hastaların anksiyete ve depresif bozukluk açısından karşılaştırmalı değerlendirilmesi. Türk Aile Hek Derg 2010;14:22-5. [CrossRef]

18. Collins MM, Corcoran P, Perry J. Anxiety and depression symptoms in patients with diabetes. Diabet Med 2008;26:153-61. [CrossRef]

19. Turhan H. Tip 2 Diabetes mellitus'lu Hastalarda Tedavi Sekline ve Hastalık Süresine Göre Depresyon ve Anksiyete. Taksim Eğitim ve Araştırma Hastanesi Aile Hekimliği Koordinatörü. Uzmanlık Tezi; 2007.

20. Sönmez B, Kasım I. Diabetes mellitus'lu hastaların anksiyete, depresyon durumları ve yaşam kalitesi düzeyleri. Türk Aile Hek Derg 2013;17:119-24. [CrossRef]

21. Bahar A, Sertbaş G, Sönmez A. Diyabetes mellitus'lu hastaların depresyon ve anksiyete düzeylerinin belirlenmesi. Anatolian Psychiatry 2006;7:18-26. Erişim: https://docplayer.biz.tr/18280144Diyabetes-mellituslu-hastalarin-depresyon-ve-anksiyeteduzeylerinin-belirlenmesi.html

22. Akkoyunlu C. Tip II Diyabet Mellit ve Romatoid Artrit Hastalarında Hastalık Algısının Depresyon, Anksiyete ve Yaşam Kalitesi ile İlişkisi. Başkent Üniversitesi Ankara Hastanesi Psikiyatri Anabilim Dalı, Uzmanlık Tezi. Ankara; 2012
23. Zigmond AS, Snaith PR. The Hospital Anxiety and Depression Scale. Acta Psychiatr Scand 1983;67:361-70. [CrossRef]

24. Aydemir Ö. Hastane Anksiyete ve Depresyon Ölçeği Türkçe formunun geçerlilik ve güvenilirlik çalışması. Türk Psikiyatri Derg 1997;8:280-7.

25. Weinman J, Petrie KJ, Moss-Morris R, Horne R. The Illness Perception Questionnaire: A New Method for Assessing the Cognitive Representation of Illness. Psychol Health 1996;11:431-45. [CrossRef]

26. Moss-Morris R, Weinman J, Petrie KJ, Horne R, Cameron LD, Buick L. The revised illness perception questionnaire (IPQ-R). Psychol Health 2002;17:1-16. [CrossRef]

27. Lloyd CE, Brown FJ. Depression and diabetes. Curr Womens Health Rep 2002;2:188-93.

28. Buzlu S. Diyabetin Psikososyal Yönü. Erdoğan S, editör. Diyabet Hemşireliği Temel Bilgiler, İstanbul: Yüce Yayım Dağıtım; 2002.

29. Acehan O. Hipertansiyon Kontrolünde Hastalık Etkisi ve Grup Görüşmelerinin Etkisi. Çukurova Üniversitesi Tıp Fakültesi, Aile Hekimliği Anabilim Dalı, Uzmanlık Tezi. Adana; 2010.

30. Kayacan Ç. Kronik Hastalıklarda Hastalık Algısının ve Etkileyen Faktörlerin Değerlendirilmesi. İstanbul Bilim Üniversitesi Sağlık Bilimleri Enstitüsü, Yüksek Lisans Tezi. İstanbul; 2012.

31. Kayış A. Kanser Hastalarının Hastalık Algısı ve Umutsuzluk Düzeyleri. Haliç Üniversitesi Sağlık Bilimleri Enstitüsü, Yüksek Lisans Tezi. İstanbul; 2009.

32. Akgüç N. Tip 2 Diyabet Hastalarında Hastalık Algısı ve Tedaviye Uyumlarının Değerlendirilmesi. Haliç Üniversitesi Sağlık Bilimleri Enstitüsü, Yüksek Lisans Tezi. İstanbul; 2013.

33. Akın AS. Tip 2 Diyabet Hastalarında Yaşam Kalitesi, Hastalıkla İlgili Bilgi Düzeyi, Hastalık Algısı, Stresle Başa Çıkma Ve Depresyon. Okan Üniversitesi. Psikoloji Anabilim Dalı, Yüksek Lisans Tezi. İstanbul; 2011.

34. Abubakari AR, Jones MC, Lauder W, Kirk A, Devendra D, Anderson J. Psychometric properties of the revised illness perception questionnaire: Factorstructure and reliability among African-origin populations with type 2 diabetes. Int J Nurs Stud 2012;49:672-81. [CrossRef]

35. Aflakseir A. Role of illness and medication perceptions on adherence to medication in a group of Iranian patients with type 2 diabetes. J Diabetes 2012:4:243-7. [CrossRef]

36. Okanovic MP, Peros K, Szabo S, Begict D, Metelko Z. Depression in Croation Type 2 diabetic patients: prevalence and risk factors. A CroationSurvey from the European Depression in Diabetes Research Consortium. Diabet Med 2005;22:942-5. [CrossRef]

37. Fisher L, Skaff MM, Mullan JT, Arean P, Glasgow R, Masharani U. Alongitudinal study of affective and anxiety disorders, depressive affect and diabetes distress in adults with Type 2 diabetes. Diabet Med 2008;25:1096-101. [CrossRef]

38. Weijman I, Kant I, Swaen GM, Ros WJ, Rutten GE, Schaufeli WB, et al. Diabetes, employment and fatigue-related complaints: a comparison between diabetic employees, "healthy" employees, and employees with other chronic diseases. J Occup Environ Med 2004;46:828-36. [CrossRef]

39. Paschalides C, Wearden AJ, Dunkerley R, Bundy C, Davies R, Dickens $\mathrm{CM}$. The associations of anxiety, depression and personal illness representations with glycaemic control and healthrelated quality of life in patients with type 2 diabetes mellitus. J Psychosom Res 2004;57:557-64. [CrossRef] 